\title{
Mining and hydraulic engineering structures as commercialized facilities
}

\author{
Vladimir Konovalov, Tatyana Yershova, and Svetlana Bedrina \\ Ural State Mining University, 620144, Kuibyshev st., 30, Yekaterinburg, Russia
}

\begin{abstract}
About 70 acting and inactive mining and hydraulic engineering structures containing considerable number of valuable components have been identified in the Ural mining region, suggesting that they can be viewed as man-made mineral fields. The paper studies an optional approach to identify these structures as real estate assets with their further record in the Unified State Register of Immovable Property and their commercialization.
\end{abstract}

Wastes of processing plants in a form of accumulated solid waste disposed in waste dumps, and liquid wastes stored in special hoppers (tailings storage and slurry storage facilities), as well as sedimentation ponds (hereinafter - mining hydraulic engineering structures (MHS), are generated in the course of extraction of mineral resources, in particular, at production and primary processing of the minerals. Herewith, the amount of waste by far exceeds amount of target components in the mineral product. This way, at least 50-60 t of waste generated at processing of produced mineral are generated per $1 \mathrm{t}$ of nonferrous metals produced [1]. The area occupied by dumped wastes resulting from minerals processing is also significant. For example, the area occupied by dumped 9 million tons of metallic wastes in North Ossetia-Alania Republic amounts to 250 ha approximately [1].

In return, the wastes of treatment facilities contain quite a lot of valuable components, whose extraction is not cost effective as of yet. As shown in reference [1], zinc and lead middlings and concentrates from $3 \%$ to $20 \%$ can be extracted from dressing plant tailings, remaining after polymetallic ores dressing; pyrite concentrate containing more than $30 \%$ of sulfur, titanium-magnesium concentrate containing more than $30 \%$ of titanium oxide can be produced. Clay-salt sludges remaining after dressing the ores produced at Verkhnekamskoye field of potassium and magnesium salt contain gold ( $0.57 \mathrm{gpt})$, platinum (9.6 gpt) and palladium (11.8 gpt) on top of magnesium, manganese and common salt [2].

More than 100 dressing plants and more than 50 metallurgic plants processing all types of minerals are operating in the Ural mining region recently (Fig. 1) [3]. More than 2 billion tons of treatment plant rejects have been aggregated at their territory, while rate of their generation is higher than 60 million tons per year [3]. 


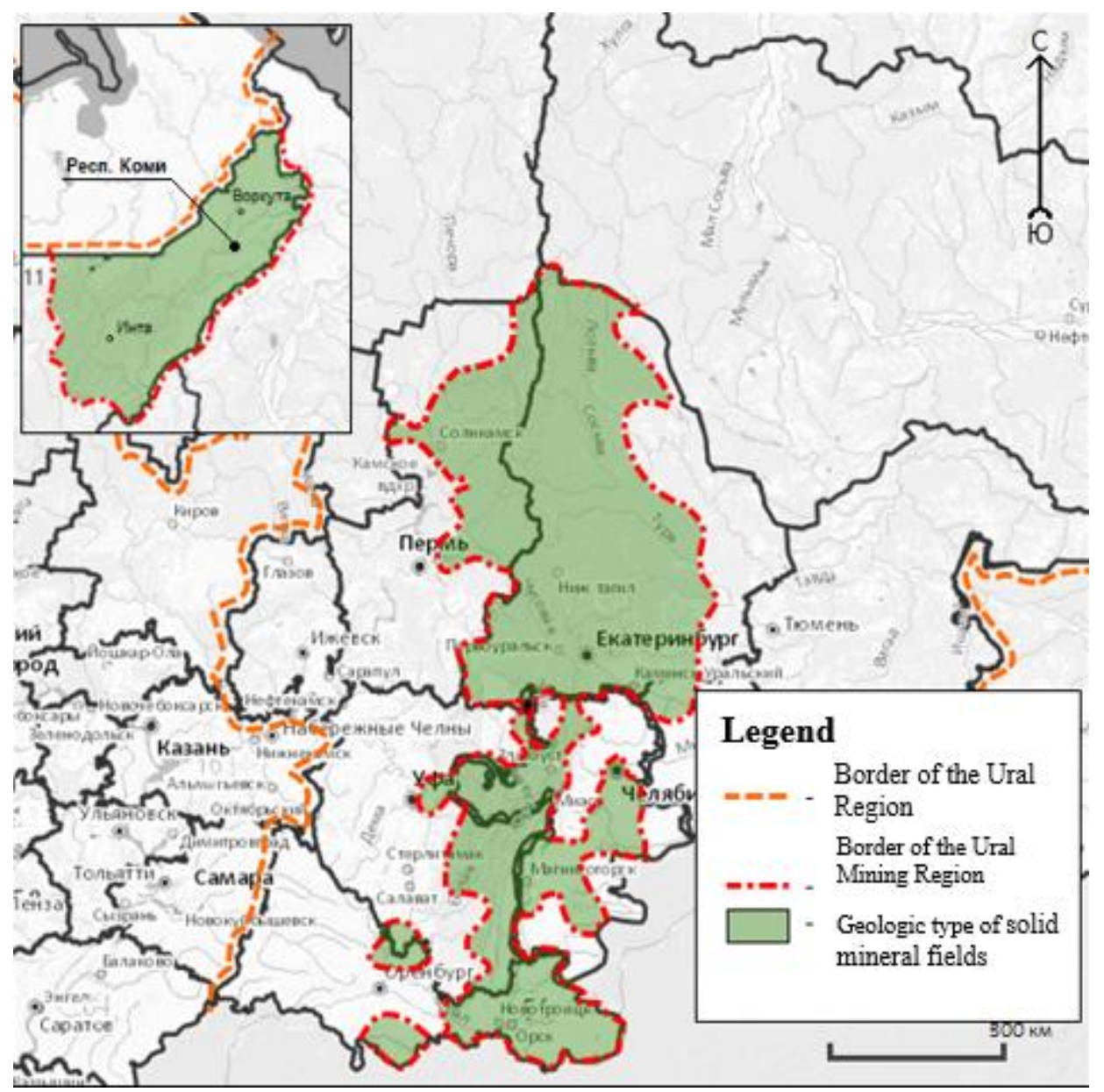

Fig. 1. The Ural mining region area (solid mineral deposits)- 29,655.1 thousand ha (11\% of the Ural Region area)

More than 30 mining and metallurgic plants have the mining and hydraulic engineering structures arranged at their territories. Some of their characteristics are summarized in the Table 1.

The area occupied by tailings storage and slurry storage facilities varies from 2.3 ha to 1,252.25 ha, gathering ponds occupy from 3.69 ha to 711.27 ha, sedimentation ponds occupy from 1.67 ha to 45.82 ha. Wide area occupied by the facilities, their number, and high volume of collected waste present an environmental challenge, while the valuable components contained in tailings of ore dressing and secondary beneficiation stage and becoming recoverable minerals present a technical problem of their extraction.

Table 1. Summary of mining and hydraulic engineering structures of the Ural mining region

\begin{tabular}{|c|l|c|c|}
\hline No. & \multicolumn{1}{|c|}{ Facilities } & Quantity & Area, ha \\
\hline 1 & Tailings and slurry storages: & & \\
& - acting & 34 & $5,628.21$ \\
& - inactive & 14 & $1,291.69$ \\
& Total & 48 & $6,919.90$ \\
\hline
\end{tabular}




\begin{tabular}{|c|l|c|c|}
\hline 2 & Clarification ponds located at: & 1 & 711.27 \\
& - active plants premises & 5 & 394.79 \\
& - shut-down plants premises & 6 & $1,106.06$ \\
\hline & Total & & \\
3 & Sedimentation ponds located at: & 4 & 86.23 \\
& - active plants premises & 11 & 171.01 \\
& - shut-down plants premises & 15 & 257.24 \\
\hline & Total & 69 & $8,283.20$ \\
\hline
\end{tabular}

For that matter, in order to utilize the generated man-made mineral fields, one of the goals established by the National Project "Ecology" [4] is to provide appropriate conditions for mining waste re-treatment, taking the best proven practices into consideration. This concept was implemented in the Russian legislation. One of such terms and conditions is identification of the mining waste storages as property assets subjected to right, so that they can be managed, owned, used, and to make provision for their commercialization.

Let's study this subject more carefully.

The term "capital construction project" is defined in Article 1 of the Urban Planning Code of the Russian Federation as "the building, structure, construction, objects which construction is not complete..., except for non-capital structures, constructions and inseparable improvements of the parcel of land (pavement, covering and others)" [5].

Whereas, as per the reference [6], "a building is the result of construction representing the volume, flat or linear construction system including surface, elevated and (or) underground parts, integrating carrier frames and, in some cases, enclosing structures, and intended for performing various production processes, storage of products, temporary accommodation of people, transportation of people and cargoes". Every individual facility with all the utilities integrated therewith is also an object classified as structure.

In this case, bearing in mind that production waste storage facility is under consideration, in accordance with the reference [7] such structure shall be considered as waste disposal facility, defined as "specially equipped structures intended for disposal of the wastes (landfill, slurry storage, incl. sludge pit, tailings storage facility, rock dump et al), and containing waste storages and waste disposal facilities".

On the other hand, the facilities in question are included but not limited to liquid waste storages, i.e., as per reference [8], hydrotechnical facilities, in particular, these are dams, and structures (dikes), enclosing the storages liquid waste of industrial enterprises, and other structures, buildings, equipment and other facilities designed for utilization of water resources and prevention of negative impact of water and liquid waste, e.g. clarification ponds and sedimentation ponds used for industrial wastewater treatment.

To be precise, the following industrial waste storage facilities are included to industrial hydrotechnical facilities: tailings storage facilities, slurry storages, hydraulic-mine dumps, sedimentation ponds, industrial wastewater, drain water and slurry storage tanks, temporary water storage basins, decommissioned liquid industrial waste storages used as man-made mineral fields [9].

Accordingly, mining hydraulic engineering structures (hereinafter - MHS) shall be further referred to as facilities designed for storage of mining wastes.

The following MHS types are identified, depending on terrain profile (Fig. 2) [10]:

a) ravine ponds are located in ravines or dammed up gullies;

b) lowland ones are designed on flat land with bounding around the perimeter. Performance value of the lowland storage is that no discharge of natural drains is required;

c) ravine and lowland ones are installed on flat terrain crossed with ravines that are dammed up, and the flat land is bounded; 
d) the flood plain storages are arranged in the flood plains of rivers and bounded around two or three sides, depending on terrain profile;

e) the side-hill storages are built on plots dammed up at three sides, and bounded by the side hill itself on the fourth one;

$f$ ) the basin type storages are located in basing of the old pits; in this case the wastes can be stored without construction of dam;

$g$ ) the basin type storages are located in basing of the old pits, in this case the wastes can be stored without construction of dam, or a low height dam is required.

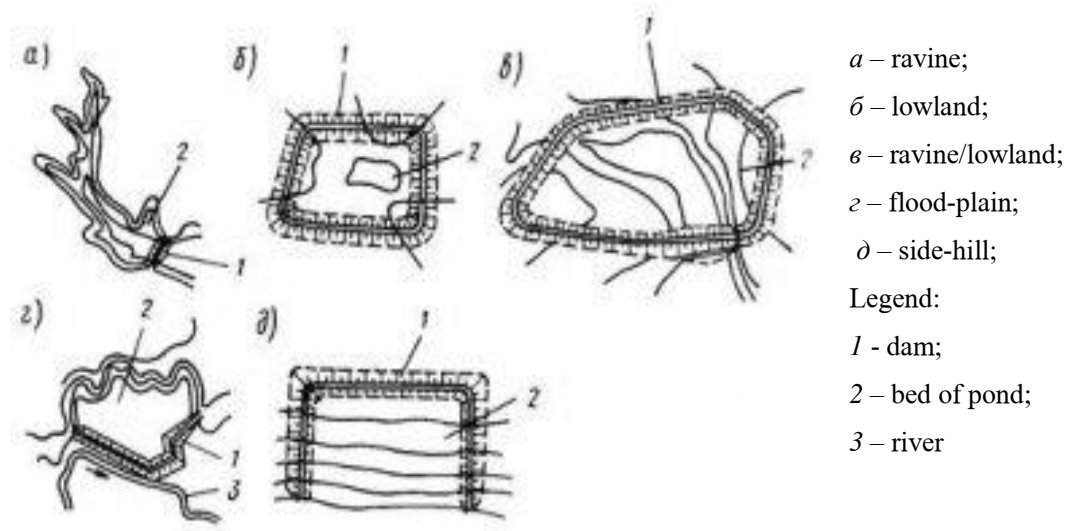

Fig. 2. Tailings and slurry storage types

Three main MHS types are identified, depending on their design features:

1. Damming (offstream) storage, in which the safety barriers are erected full height immediately.

2. Gradual fill structure, in which a starting dyke of small height, required to ensure a washover fill, is built first, with the height to be increased gradually by construction of the second bounding dyke at later stage.

3.Damless storage, in which neither dam, nor starting dyke are built.

From MHS design perspective, the structures consist of:

- the basin of structure, including the bottom with watertight screen, bund walls and supporting dams, including drainage and watertight units. The dams are divided into starting dam and flood breaking dams to be topped as the storage basin is filled up;

- slurry pumping station, main and distribution slurry trays or pipe lines arranged on crossbeams or racks;

- drain (draw-off) sump, spillway collector;

- pump stations, recycling water supply pumps;

- accidental discharge drain (catch drain).

Figure 3 shows general layout of the liquid waste storage facility. 


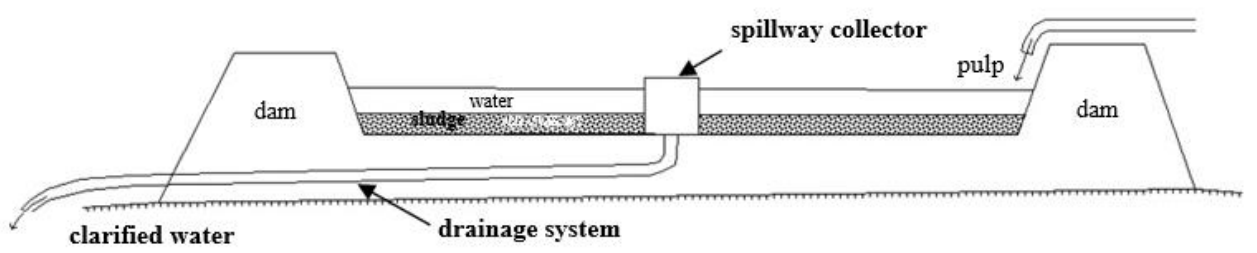

Fig. 3. General layout of the liquid mining waste storage facility

The facilities represent embanked open basins (Fig. 3), subjected to preservation after relevant amount of slurry (tailings) build up, and the slurry (tailings) are then transferred to other storage tanks. Both facilities are usually arranged outside of the plant premises, and slurries are transferred via pipelines or delivered by motor vehicles.

Drainage systems maintaining required level of the hydraulic grade line on surrounding territory are of great importance. In addition, drainage systems protect the soil under the structures from dangerous distortions and ensure diversion of polluted drains from the soil for its re-use or decontamination.

The MHS can be considered an adequate structure by definition, provided the listed structure components are available, which, in return, enables identifying it as a real property asset. Identifiers of the real property assets are established as the main concept (solid link with land) by the Civil Code of the Russian Federation (Article 130) [11], and gained further elaboration in the civil law. The general real property asset identifying criteria [12] are summarized in the Table 2.

Analysis of the Table 2 shows that a dike with solid link to land is a constructional component of dam (offstream) type MHS and gradual fill MHS; the dam doesn't change either its location or dimensions till end of its life, even though the level of waste contained therein does change; they are also listed as corporate property and have value. Therefore, these are real property assets and can be the subject matter of law according to criteria specified in the Table 2.

Table 2. Key criteria established for real property

\begin{tabular}{|l|l|}
\hline \multicolumn{1}{|c|}{ Criteria } & \multicolumn{1}{|c|}{ Structure (condition) } \\
\hline Degree of movement & $\begin{array}{l}\text { Absolutely immovable. Immovability in space } \\
\text { (without harming the purpose), permanence }\end{array}$ \\
\hline Link with land & Solid: physical, legal \\
\hline Functioning form & $\begin{array}{l}\text { Material value (payment-in-kind) } \\
\text { Value form }\end{array}$ \\
\hline Status of pattern of consumption during life & $\begin{array}{l}\text { Not consumed (permanence of parameters). Natural } \\
\text { shape is maintained through the whole life }\end{array}$ \\
\hline Durability (rotation cycle) & $\begin{array}{l}\text { Multiple utilization of land (unlimited with proper } \\
\text { use) }\end{array}$ \\
\hline Social implications (usefulness) & $\begin{array}{l}\text { Use of property often affects the interests of many } \\
\text { people } \\
\text { Liquidity }\end{array}$ \\
\hline \multicolumn{1}{|c|}{ Specific (individual) } \\
\hline Purpose & Functional (functional and technological) \\
\hline Technical and process features & Location, condition et al. Specific individual \\
\hline
\end{tabular}


indicators depending on type of property

Damless storage, which doesn't make provision for construction of either dam or starting dyke can't be viewed as real property asset because no criteria of the real property are met.

The bare fact that MHS are recognized as real property assets is confirmed by cadastral registration of some mining and hydraulic engineering structures: tailings dumps (old and new ones) on the land of the Stock Company "Malyshevskoye Mining Administration" (Malyshev work settlement), settlement pond on the land of OJSC "Kirovgrad Metallurgic Company" (the town of Kirovgrad).

Let's study the tailings storage facility located at OJSC "Kirovgrad Metallurgic Company" as an example. The company is located to the south-west of Kirovgrad town and occupies total area of about 657 ha. The complex consists of the following facilities: industrial site, blast furnace slag disposal area, railroad station, settlement pond, skimmings dump, treatment plants, tailings dumps (active and preserved) (Fig. 4).

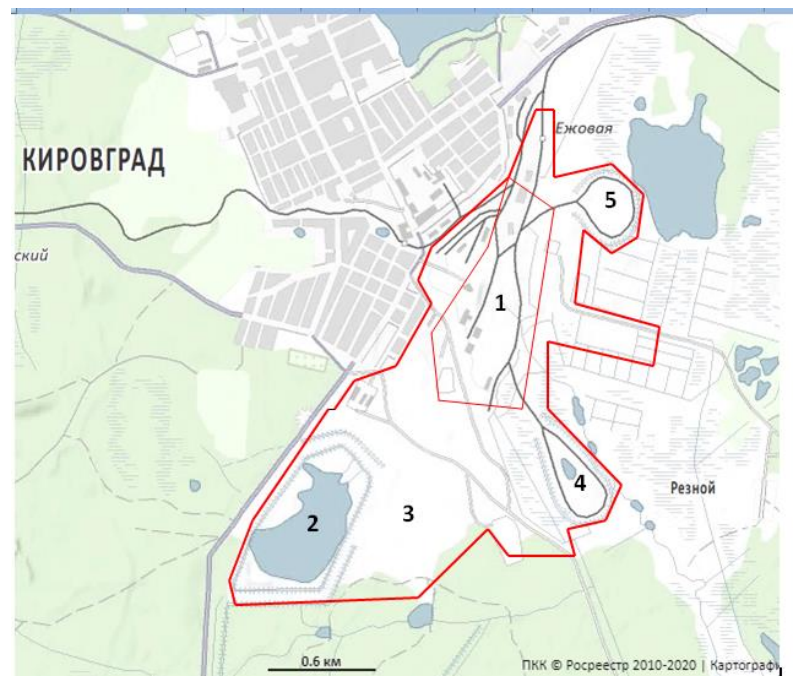

Legend

boundary of OJSC

"Kirovgrad

Metallurgic

Company"

boundary of industrial site

Fig. 4. OJSC "Kirovgrad Metallurgic Company" site layout: 1 - main industry, 2 - acting tailings dump, 3 - preserved tailings dump, 4 - skimmings dump, 5 - slag disposal area

The satellite image below (Fig. 5) shows the process complex of acting tailings dump. The red lines highlight boundaries of land plots.

It is clear from the image that the asset (tailings dump) is immovable in space and has specific location, viz. occupies a registered plot of land with assigned cadastral number 66:49:0504001:13 and area 117.74 ha; it has solid (physical) link with the land, it features engineering structures (embanking dams), and is intended for long-term use and used for specific process purposes. 


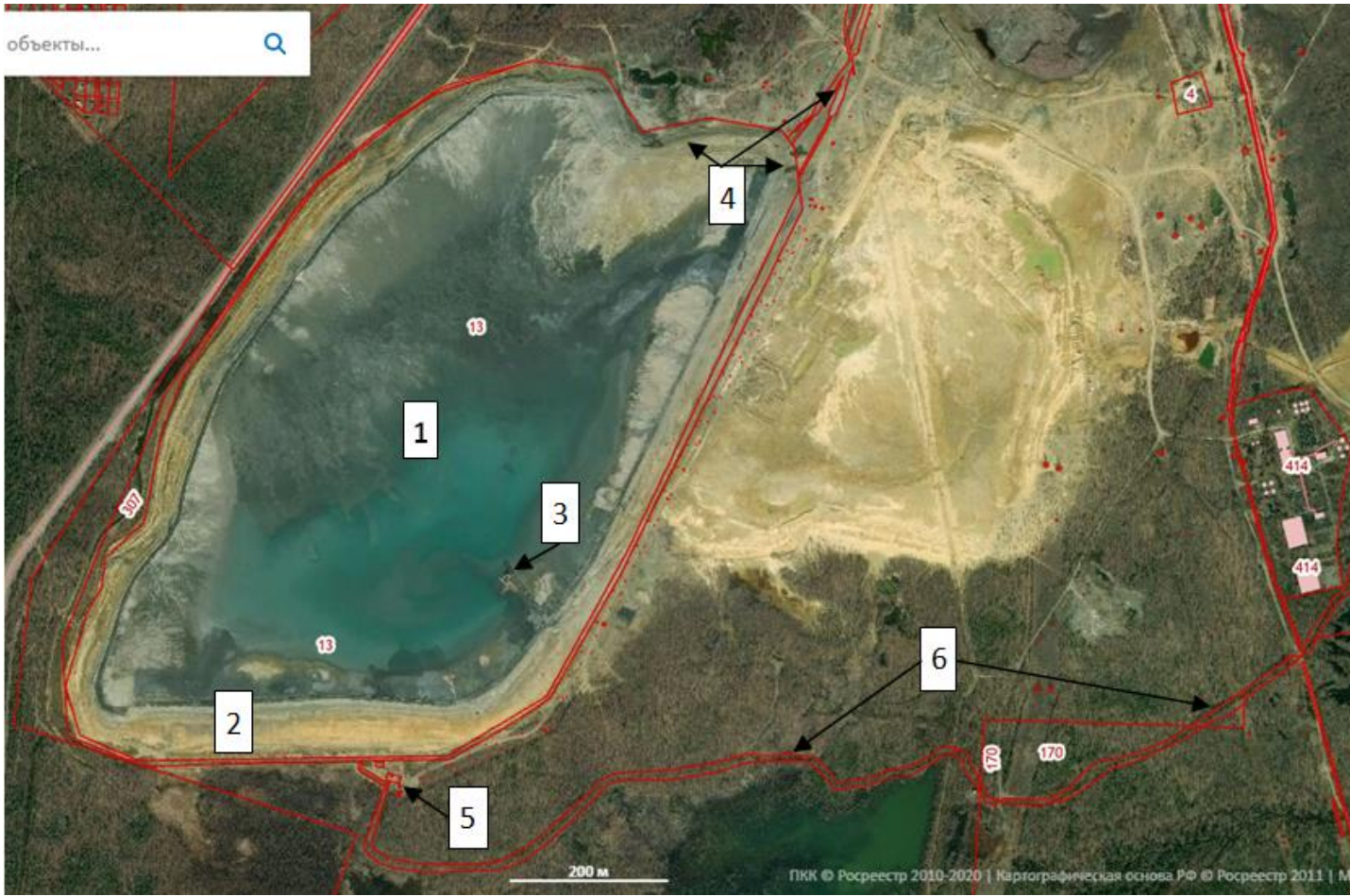

1 - basin (settlement pond), 2 - embankment, 3 - drainage sump, 4 - pulp lines, 5 - pumping station, 6 - catch drain of accidental clarified water discharge

Fig. 5. Process complex of acting tailings dump

This way, such structure can be identified as real property asset (Table 3) [12].

It should be pointed out that analysis of the Fig. 5 suggests that waste dumping in hydraulic engineering structures is a process involving transportation of pulp via main pipelines and its collection in tailings dump, and drainage system to discharge excess clarified water.

Table 3. Criteria to include storage facilities of processing plants waste (tailings storage or slurry storage facilities) to real property assets

\begin{tabular}{|c|l|c|}
\hline No. & \multicolumn{1}{|c|}{ Property criteria } & Availability \\
\hline 1 & Permanence (general location doesn't change) & available \\
\hline 2 & Solid link with land & available \\
\hline 3 & $\begin{array}{l}\text { Functioning form: } \\
\text { material } \\
\text { value form }\end{array}$ & $\begin{array}{c}\text { available } \\
\text { yes }\end{array}$ \\
\hline 4 & $\begin{array}{l}\text { Status of consumption pattern (permanence of parameters } \\
\text { during usage) }\end{array}$ & available \\
\hline 5 & Durability & yes \\
\hline 6 & Purpose (process cycle facility) & available \\
\hline & Final conclusion & is a real property asset \\
\hline & Can it be a subject matter of rights? & it can be \\
\hline
\end{tabular}


For standard and safe usage of the structure this process requires uninterrupted collaboration of all links of the processing chain, therefore the structure can be classified as an integrated property complex [11] along with the summary of land plots, established for each real property asset individually.

Therefore, the mining and hydraulic engineering structures, viz. tailings storage and slurry storage facilities, clarification ponds, sedimentation ponds, hydraulic waste disposals etc. are real estate assets with integrated engineering structures, they are registered in the company's balance sheet; and they can be recorded in the Unified State Register of Real Estate both as individual facilities, and as integrated property complexes. The property registration issued for these structures enables their commercialization.

\section{References}

1. V.I. Golik, V.I. Kamashchenko, I.V. Leonov, Mining and Environment: Training aid for Universities, 210 (Moscow: Academic Project, Culture, 2011)

2. Converting potassium wastes to gold, URL:www.newsko.ru

3. V.S. Khokhryakova The Ural's input in the Russian mining over 300 years. The Ural's Mining Cyclopedia, 500 (Yekaterinburg: Ural State Mining University Press, 2000)

4. National Project "Ecology" Design Abstract, Protocol No. 16 of the Russian Presidential Council for Strategic Development and National Projects dated 24.12.2018.

5. Urban Planning Code of the Russian Federation, dated 29.12.2004 № 190- FL

6. Technical Regulations on Safety of Buildings and Structures, dated 30.12.2009 № 384FZ

7. On Production and Consumption Waste, dated 24.06.1998 № 89- FL

8. On Safety of Hydraulic Structures, dated 21.07.1997 № 117- FL

9. Resolution of the Federal Mining and Industrial Supervision of Russia dated 12.01.1998 № RD 03-259-98.

10. Metal industry slurry reservoir and tailings storage facility design and construction guide (Moscow: Stroyizdat, 1986)

11. Civil Code of the Russian Federation, Part 1, dated 30.11.1994№ 51-FL

12. V.E. Konovalov, Inventory of the mining facilities, 168 (Yekaterinburg: Ural State Mining University Press, 2012) 